\title{
Mathematical Modeling of Groundwater Level Changing with Considering Evapotranspiration Factor
}

\author{
E.N.Sierikova ${ }^{1^{*}}$, E.A. Strelnikova ${ }^{2}$ \\ ${ }^{I}$ PhD, senior lecturer, National University of Civil Defence of Ukraine, Chernyshevska str., 94, Kharkiv, \\ Ukraine, \\ ${ }^{2}$ Doctor of Technical Sciences, leading researcher, A.M. Pidhorny Institute for Mechanical Engineering \\ Problems NAS of Ukraine
}

*Corresponding Author: E.N.Sierikova, PhD, senior lecturer, National University of Civil Defence of Ukraine, Chernyshevska str., 94, Kharkiv, Ukraine.

\begin{abstract}
Paper elucidates the mathematical modeling of groundwater level changing with considering evaportanspiration factor. The objective is to improve the forecasts of groundwater level changes for increasing environmental safety of urban areas flooded by groundwater. Developed mathematical model takes into account the essential balance components, such as groundwater replenishment by atmospheric waters, additional groundwater replenishment, evapotranspiration and water extraction from underground waters. The calculation results on the model have determined the close correlation between the calculated and actual monitoring values of groundwater levels.
\end{abstract}

Keywords: Evapotranspiration, groundwater level, mathematical modeling, flooding, additional groundwater replenishment, groundwater balance, groundwater level monitoring.

\section{INTRODUCTION}

For a significant number of cities in Ukraine increasing the systematic average groundwater level on the built-up areas and expansion of the flooding areas has been characterized by following scientists: Abramov S. K., 2009 [1]; Chebanov A. Yu., 2002 [2]; Shvets V. Y., 2003; Strigelchik G.G., 2003 [3]; Telima S. V., 2006 [4]; Vigva S. A., 2010; Yakovlev Ye. O., 2003 [5]; Yatsik A. V. [6], 2002 and others. For 2011-2014 the flooding area of the Ukraine's territory amounted 7,9 million hectares [711], and the number of flooded settlements amounted 4702. Moreover, for 2018 year the flooding area amounted 8,9 million hectares, and the number of flooded settlements amounted 4747 [12]. This list starts with the big cities of Ukraine.

As a flooding result the materials of underground communications can be destroyed, there are marshy areas and flooded underground premises in residential buildings. This leads to the mosquito's appearance, the fungi development, poisonous vapors in the air, which adversely affects the population health and leads to significant material damage. In addition, accidents in sewage systems and increased infiltration from the surface have led to significant pollution of the upper groundwater horizons, and their unsuitability for drinking water consumption [13].

Known scientists and specialists, in particular: Abramov S.K., Chebanov O.Yu., Degtyarev B.M., Dzektser Y.S., Muftahov A.G., Sologayev V.I., Strizelchik G.G., Yakovlev Ye.A. And others studied the dynamics of groundwater level changes and developed the flooding process of urban and industrial territories. At the present time, the tasks of the integrated assessment of the Ukraine's large cities technogenic impact on the groundwater level and its change forecasting, taking into account indepth research and mathematical models development for increasing the ecological safety of urban areas with flooding risk, remain relevant $[1,2,5,14]$.

The objective is to improve the forecasts of groundwater level changes for increasing environmental safety of urban areas flooded by groundwater. 


\section{MAterials And Methods}

For modeling the groundwater level changes on the Kharkiv city example, the typical part of the territory, partially covered with artificial surfaces on the soil, has been described in the paper. There are influences of natural and technogenic factors take place only on the free surface of this territory.

Developed mathematical model $[15,16]$ considers the leading balance components, such as groundwater replenishment by atmospheric waters, additional groundwater replenishment, evapotranspiration and water extraction from underground waters. Boundary conditions characterized the areas without infiltration process, additional replenishment, evapotranspiration, and the areas with these processes have been considered in the paper. Including additional groundwater replenishment, evapotranspiration, water extraction, and the symmetric model has been considered. The mathematical model has been specified by the boundary value problem for the differential filtration equation.

The stationary filtration equation has the follow form:

$$
\frac{\partial^{2} h}{\partial x^{2}}+\gamma^{2} \frac{\partial^{2} h}{\partial y^{2}}=0
$$

Where $h(x, y)$ - groundwater level, $\gamma$ is an anisotropy coefficient, characterized the environmental properties difference in different directions.

Scheme of calculated area is shown on Fig. 1.

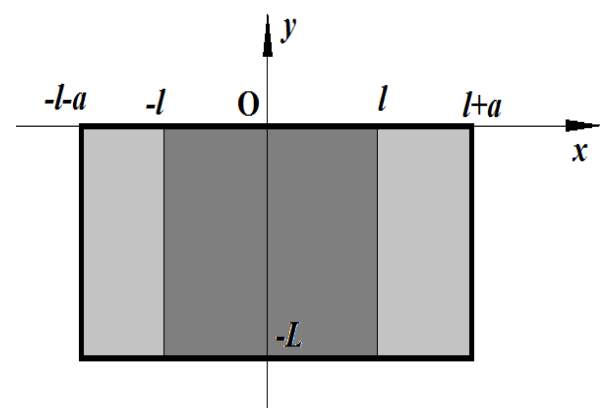

Figure1. Scheme of Calculated Area.

Solution of equation (1) requires the boundary conditions definition. Since changes of groundwater levels and their distribution are local and simulation is carried out for limited urban territory areas (industrial objects, buildings, etc.), with homogeneous hydrogeological conditions, it could be assumed that the lateral inflow and outflow are equal, so

$$
\left\{\begin{array}{l}
\left.\frac{\partial h}{\partial x}\right|_{x=l+a}=e_{1}(y) \\
\left.\frac{\partial h}{\partial x}\right|_{x=-l-a}=e_{1}(y)
\end{array}, e_{1}(y)=\frac{2}{1+\left(y / y_{50}\right)^{\tau}},\right.
$$

where $x=0$ is the ground surface, $\tau$ is for relative variability of potential transpiration; $y_{50}$ is a parameter characterizing the height of water capillary absorption; $y$ be depth where the suction pressure of moisture occurs. Here in after $\tau=2,2 ; y_{50}=3$ according to [17].

The starting level is taken as a reference point, $h=0$

$\left.h\right|_{y=0}=0$,

We accept that on $[-l, l]$ (Fig. 1.) there are no water extraction, evapotranspiration and groundwater replenishment by atmospheric waters through the artificial surfaces. There is only additional groundwater replenishment.

$\left.\frac{\partial h}{\partial y}\right|_{-l \leq x \leq l}=0$. 
But on the plots $[-l-a,-l]$ and $[l, l+a]$ (Fig.1.) there are water extraction, additional groundwater replenishment, evapotranspiration and groundwater replenishment by atmospheric waters.

$$
\begin{aligned}
& \left.\frac{\partial h}{\partial y}\right|_{l \leq x \leq l+a, y=0}=f_{1}+s_{1}-k_{1}, \\
& \left.\frac{\partial h}{\partial y}\right|_{-l \leq x \leq-l-a, y=0}=f_{1}+s_{1}-k_{1},
\end{aligned}
$$

Where $f_{l}$ is the additional groundwater replenishment (profitable part of groundwater balance); $s_{l}$ is the groundwater replenishment by atmospheric waters (profitable part of groundwater balance); $e_{1}$ is for evapotranspiration, depended of groundwater depth (expenditure part of groundwater balance); $k_{1}$ is the groundwater extraction (expenditure part of groundwater balance). A similar condition has been put on the plot $[-l-a \div-l][15,16,18]$.

The solution of boundary value problem (1) - (5) consists of the sum of two boundary problems solutions $h=h_{1}+h_{2}$. The formulation of it is given below.

$$
\begin{aligned}
& \left\{\begin{array}{l}
\frac{\partial^{2} h_{1}}{\partial x^{2}}+\gamma^{2} \frac{\partial^{2} h_{1}}{\partial y^{2}}=0 \\
\left.h_{1}\right|_{y=0}=0 \\
\left.\frac{\partial h_{1}}{\partial y}\right|_{-l-a \leq x \leq l+a}=0 \\
\left.\frac{\partial h_{1}}{\partial x}\right|_{x= \pm(l+a)}=e_{1}(y)
\end{array}\right. \\
& \left\{\begin{array}{l}
\frac{\partial^{2} h_{2}}{\partial x^{2}}+\gamma^{2} \frac{\partial^{2} h_{2}}{\partial y^{2}}=0 \\
\left.h_{2}\right|_{y=0}=0 \\
\left.\frac{\partial h_{2}}{\partial y}\right|_{-l \leq x \leq l}=0 ; \\
\left.\frac{\partial h_{2}}{\partial y}\right|_{-l-a \leq x<-l}=f_{1}+s_{1}-k_{1} \\
\left.\frac{\partial h_{2}}{\partial y}\right|_{l<x \leq l+a}=f_{1}+s_{1}-k_{1} \\
\left.\frac{\partial h_{2}}{\partial x}\right|_{x= \pm(l+a)}=0
\end{array}\right.
\end{aligned}
$$

The solution of boundary value problem (6) describes the effect on the groundwater level provoked by the evapotranspiration, depending on the depth, but without considering the influence of atmospheric precipitation and additional groundwater replenishment, while the solution of boundary value problem (7) takes into account the additional groundwater replenishment on separate plots, but does not take into consideration the evapotranspiration depth changes. Problems (6), (7) are solved by decomposition into Fourier series. A numerical analysis realized using the Maple package demonstrated that five members of the series are sufficient to ensure the accuracy of the solution $\varepsilon=$ $10^{-3}$.

The value of the groundwater level changing in the unchanged evapotranspiration conditions, visualized by calculations for the limited areas of Kharkiv city in Fig. 2, where depicted the function $h_{2}(x, y)$, has been obtained. Also, the value of the groundwater level changing with a variable evapotranspiration has been obtained, (Fig.3.). 


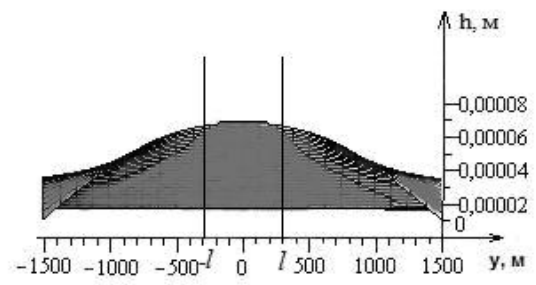

Figure2. Average Daily Groundwater Level Changing According to Model Profile, Without Taking into Account the Effect of Evapotranspiration

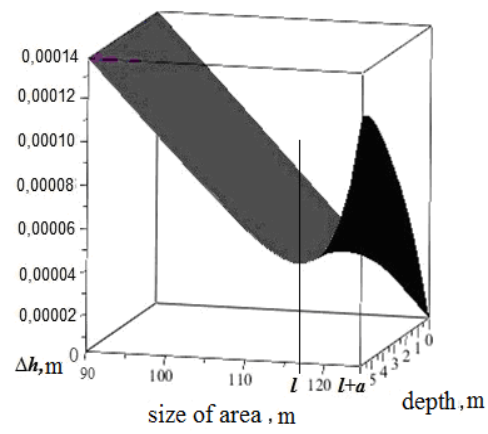

Figure3. 3D Model, Average Daily Groundwater Level Changing According to Evapotranspiration Effect.

\subsection{Discussion of Simulation Results}

The prediction of maximum groundwater level altitude (Fig.2.) for the Kharkiv city, without taking into consideration the evapotranspiration effect on the 50 years perspective, indicates that for the $1^{\text {st }}$ year the level rise will be $0,03 \mathrm{~m}$, and for the $50^{\text {th }}$ year near $1,5 \mathrm{~m}$. In order to optimize groundwater balance for the ensuring environmental safety of urban flooded territories the expense and profitable groundwater parts balancing are conducted. Balancing occurs by the additional groundwater replenishment reducing in 2,4 times, that means to reduce additional groundwater replenishment an average on $240,000 \mathrm{~m}^{3} / \mathrm{day}$, and increase the groundwater extraction in 15 times, that corresponds an average $300,000 \mathrm{~m}^{3} /$ day. The total amount of pumped groundwater in this case will be 540000 $\mathrm{m}^{3} /$ day. As the quality of groundwater in Kharkiv is low, the calculated water volume could be used for technical purposes - road and sidewalks washing, car washing, pouring of rollers and irrigation of plants, in construction and industrial cooling and heat supply systems, for fire extinguishing and other areas [16].

Also, the prediction of groundwater level changing included evapotranspiration effect (Fig. 3) for the 50 years future has been provided in the paper. Under artificial covers for the $1^{\text {st }}$ year, there will be $0,05 \mathrm{~m}$ of the level rising, and for the $50^{\text {th }}$ year it will be $2,56 \mathrm{~m}$. On the territory, free of artificial covers, groundwater level will be stabilized by the evapotranspiration action. Thus, the proliferation of artificial surfaces in the city will contribute reducing the evapotranspiration effect and groundwater level sustained increase and flood development [13, 19].

\subsection{Adequacy Evaluation of Proposed Mathematical Model}

The adequacy evaluation of the proposed model is carried out on two different landscaped areas. The first section is mainly located in the middle of the private sector, and has a free surface. The second section is practically completely covered with artificial covers [13].

The first section, where retrospective data are available, is located in the historic central part of the Kharkiv city, and limited by the lane Banni, the Proletarska, Pavlivska and Ribna squares, Universitetska str. Geomorphologically, section is located within the floodplain at the confluence of Lopan River and Kharkiv River. The water level in the rivers is regulated by the Goncharivka damba with a marking $100.5 \mathrm{~m}$. The intensive development of this territory caused additional technogenic factors of influencing for groundwater level increasing. The plot is almost fullness covered with artificial covers.

The engineering and geological surveys on this section were carried out by the Ukrainian main industrial research and engineering institute of engineering and environmental research 
(UkrNIIINTIZ) for the period from 1965 to 2016. All the mentioned control points (observation wells) are located in one - the first from the surface aquifer (Fig 4.).

The second section is where the author Serikova E.N. carried out research as a Geological Party worker-observer in the work on observation water points in Kharkiv, equipped on groundwater. The groundwater level measurement in specially equipped and adapted for these wells was carried out with the help of the GRU-100 level gauge with 1 time per month intervals during 2004-2017 [13].

Location of observation posts and control points for groundwater level, considered in the work, are given in Fig. 4

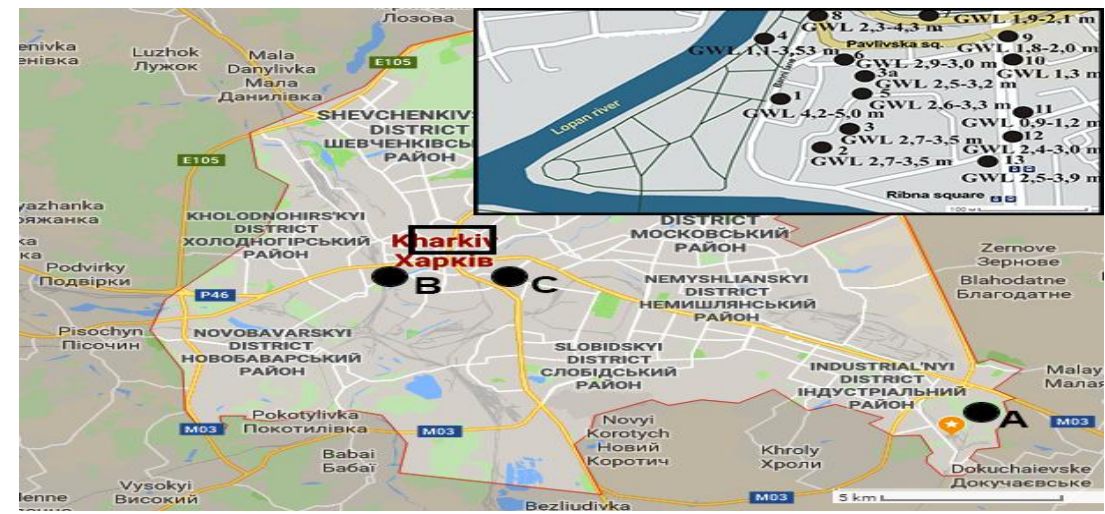

Figure4. Points of Groundwater Level Observation for the Period Ffrom 1965 To 2017.

Points A, B, C are duty water points of the state observation network in Kharkiv, and points 1-13 are special observation points of the Ukrainian Main Industrial Research Institute of Engineering and Environmental Surveys (UkrNIIINTIZ) for groundwater level changing monitoring in which measurements were made [13].

The intensity of groundwater level reduction under the evapotranspiration influence is shown in Fig. 5.

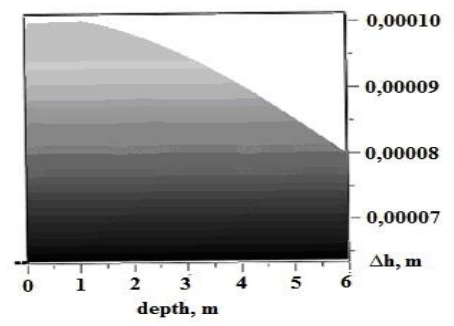

Figure5. The Intensity of Groundwater Level Reduction under the Evapotranspiration Influence.

Comparison of monitoring data with predicted groundwater level changes is given in the Table. 1

Table1. Comparison of Monitoring Data with Predicted Groundwater Level Changes.

\begin{tabular}{|c|c|c|c|c|c|}
\hline Point № & $\begin{array}{c}\text { Actual } \\
\text { depth of } \\
\text { groundwater } \\
\text { level }\end{array}$ & Research year, & $\begin{array}{c}\text { Actual } \\
\text { groundwater } \\
\text { level } \\
\text { change, } \mathrm{m}\end{array}$ & $\begin{array}{c}\text { Groundwater level } \\
\text { changing on the model } \\
\text { without } \\
\text { evapotranspiration } \\
\text { effect, } m\end{array}$ & $\begin{array}{l}\text { Groundwater level } \\
\text { changing on the model } \\
\text { according to } \\
\text { evapotranspiration } \\
\text { effect, } m\end{array}$ \\
\hline 2 & $2,7-3,5$ & 1978 & \multirow[t]{2}{*}{$1,4-2,2$} & \multirow[t]{2}{*}{2,08} & \multirow[t]{2}{*}{1,25} \\
\hline 10 & 1,3 & 2016 & & & \\
\hline 1 & $4,2-5,0$ & 1965 & \multirow[t]{2}{*}{$1,6-1,7$} & \multirow[t]{2}{*}{1,97} & \multirow[t]{2}{*}{1,45} \\
\hline 5 & $2,6-3,3$ & 2001 & & & \\
\hline 8 & $2,3-4,3$ & 1993 & \multirow[t]{2}{*}{$-0,6-1,3 *$} & \multirow[t]{2}{*}{0,44} & \multirow[t]{2}{*}{$-0,27-0,23$} \\
\hline 6 & $2,9-3,0$ & 2001 & & & \\
\hline \multirow[t]{2}{*}{$\mathrm{A}$} & 5,10 & 2004 & \multirow[t]{2}{*}{$-0,3^{*}$} & \multirow{2}{*}{$\begin{array}{c}\text { Can not be taken into } \\
\text { account }\end{array}$} & \multirow[t]{2}{*}{$-0,40^{*}$} \\
\hline & 5,40 & 2017 & & & \\
\hline \multirow[t]{2}{*}{$\mathrm{B}$} & 2,37 & 2004 & \multirow[t]{2}{*}{$-0,45^{*}$} & \multirow{2}{*}{$\begin{array}{c}\text { Can not be taken into } \\
\text { account }\end{array}$} & \multirow[t]{2}{*}{$-0,45^{*}$} \\
\hline & 2,82 & 2017 & & & \\
\hline
\end{tabular}


* - reduce of groundwater level.

Comparison of simulation results and data of field observations indicates the adequacy of created model by the actual data presented in Table 1. Taking into account the evapotranspiration effect with depth makes it possible to create more precise forecast of groundwater level changes. Thus, the evapotranspiration effect stabilizes and reduces the groundwater level (points A, B), and on the territories with artificial covers (points $1,2,3,5,6,8,10$ ), the evapotranspiration effect is impossible; therefore, the rise of groundwater level is occurring.

\section{CONCLUSiON}

For the first time, mathematical model for the groundwater level changing has been developed, which takes into account the influence of artificial surface covers and evapotranspiration. The forecast variant of the groundwater level maximum rising in the conditions of natural technogenic geosystems of large cities has been developed on the Kharkiv city example. The optimization groundwater balance measures have been proposed due to taking into account influence of technogenic factors on groundwater. The assessment of their effectiveness, which provides environmental safety increasing of Ukrainian cities, has been provided in the paper.

Adequacy evaluation of proposed mathematical model on the actual groundwater level monitoring data has been realized. The calculation results on the model have determined the close correlation between the calculated and actual monitoring values of groundwater levels. This indicates the adequacy of created mathematical model to real physical conditions.

\section{REFERENCES}

[1] Abramov S. K., Degtyarev B. M. and Dzekcer E. S., 1972. The sources and factors of industrial enterprises flooding areas.- Materials of Union inter-sectoral meeting "Forecast problems of groundwater level increasing on the built-up areas and flooding fighting". Belgorod. pp. 57-61.

[2] Chebanov, A. Y., 2002. The search for effective solutions of the flooding problem in cities. KNAME, Kharkiv. pp. 133-138.

[3] Strigelchik G., Sokolov Y., Goldfeld I., Chebanov A. and Nikolenko N., 2003. Underflooding at the urban settlements of Kharkiv region. - Kharkiv. $160 \mathrm{p}$.

[4] Telima S. V., Revyakina N. Y., 2011. Model research processes of flooding by groundwater of urban areas in modern conditions. Proc.: Environmental Safety and Nature Resources №7, Kiev. pp. 45-63.

[5] Yakovlev E. O., Trofimchuk O. M., Zakorchevna N. B., Gosk E., 2003. Regional flooding of cities and villages of Ukraine as a factor of its national safety. Ecology of the environment and life safety. № 6. pp. $12-23$.

[6] Yatsik A. V., 2002. Lands flooding in Ukraine. Questions of chemistry and chemical technology. № 5. pp. 292-295.

[7] Information yearbook concerning to the activation of the dangerous exogenic geological processes on the territory of Ukraine according to the monitoring of EGP, 2011. Ministry of the Environment of Ukraine, State geological department, Sate information geological fond of Ukraine. Kiev, 88.

[8] Information yearbook concerning to the activation of the dangerous exogenic geological processes on the territory of Ukraine according to the monitoring of EGP, 2012. Ministry of the Environment of Ukraine, State geological department, Sate information geological fond of Ukraine. Kiev, 105.

[9] Information yearbook concerning to the activation of the dangerous exogenic geological processes on the territory of Ukraine according to the monitoring of EGP, 2013. Ministry of the Environment of Ukraine, State geological department, Sate information geological fond of Ukraine. Kiev, 98.

[10] Information yearbook concerning to the activation of the dangerous exogenic geological processes on the territory of Ukraine according to the monitoring of EGP, 2014. Ministry of the Environment of Ukraine, State geological department, Sate information geological fond of Ukraine. Vol. 11, Kiev, 101.

[11] Information yearbook concerning to the activation of the dangerous exogenic geological processes on the territory of Ukraine according to the monitoring of EGP, 2015. Ministry of the Environment of Ukraine, State geological department, Sate information geological fond of Ukraine. Kiev, 55.

[12] Information yearbook concerning to the activation of the dangerous exogenic geological processes on the territory of Ukraine according to the monitoring of EGP, 2018. Ministry of the Environment of Ukraine, State geological department, Sate information geological fond of Ukraine. Vol. 15, Kiev, 98. 
[13] Serikova E. N., Strelnikova E. A., Yakovlev V. V., Anishenko L. Y., Pisnya L. A., 2017. Evaluation of the adequacy of proposed prediction mathematical model on the actual data of groundwater level monitoring in the central part of kharkov city. Scientific Journal «ScienceRise» №11(40) . Kharkiv. pp. 43-47.

[14] Muftahov A. G., Korinchenko I. V., Grigoreva N.M., Sologaev V. I. and Shevchik A. P., 1991. Flooding forecasts and calculation of drainage systems in build-up and builtup areas: Reference Guide to the building regulations. Moskow. 272p.

[15] Serikova E.N., Strelnikova E.A., 2013. The treatment of characteristics of groundwater level changing via the mathematical modeling. Eastern European Journal of Enterprise Technologies №3/4, Kharkiv. pp. 3135 .

[16] Serikova E., Strelnikova E., Yakovlev V., 2015. Mathematical Model of Dangerous Changing the Groundwater Level in Ukrainian Industrial Cities. Journal of Environment Protection and Sustainable Development, USA, Vol. 1, №. 2. pp. 86-90.

[17] Gavich I. K., Zekcer I. S., Kovalevsky V. S. et al., 1983. Fundamentals of hydrogeology. Hydrogeodynamics. Science. Novosibirsk. 241 p.

[18] Serikova E.N., Yakovlev V.V., 2011. Additional infiltration to underground waters of big cities territory (on example Kharkiv region). In: Babaev V.N. (Ed.): Proc.: Municipal Economy of Cities №97, Kharkiv, KNAME. pp. 344-348.

[19] Serikova E. Strelnikova E., 2016. Groundwater Level Changing in the Urban Kharkov Ecosystem. Bulletin of NTU “KhPI”. Series: Mechanical-technological systems and complexes. - Kharkov: NTU “KhPI” № 4 (1176). pp. 132-137.

Citation: E.N.Sierikova \& E.A. Strelnikova (2020) "Mathematical Modeling of Groundwater Level Changing with Considering Evapotranspiration Factor”, International Journal of Modern Studies in Mechanical Engineering, 6(1), pp. 19-25. DOI: http://dx.doi. org/10.20431/2454-9711.0601003.

Copyright: () 2020 Authors, This is an open-access article distributed under the terms of the Creative Commons Attribution License, which permits unrestricted use, distribution, and reproduction in any medium, provided the original author and source are credited. 